\title{
Euphemisms for Taboo Words: Iliganon's Sociolinguistical Approach for Social Harmony
}

\author{
Prof. Marilyn Tampos-Villadolid \\ Department of Social Sciences and Humanities \\ College of Education and Social Sciences \\ Mindanao State University-Naawan \\ 9023 Naawan, Misamis Oriental, Philippines \\ Dr. Angelina Lozada Santos \\ Department of Filipino and Other Languages \\ College of Arts and Social Sciences \\ Mindanao State University-Iligan \\ Institute of Technology \\ 9200 Iligan City, Lanao del Norte, Philippines
}

\begin{abstract}
Iliganon's are local residents of Iligan City in Mindanao Island in southern Philippines. They are conservative and generally peace-loving. They do not provoke or start a discord or use a language that is socially unacceptable. Hence, words that have negative effect to listeners are taboo, and to push through the message they want to convey, euphemisms are used. Quota, purposive, and convenience samplings were utilized to attain the desired number of respondents classified as professionals and non-professionals, male and female. The openended questionnaire used contained a list of local taboo words which have heavy sexual meanings, repulsive dirt emanating from the body, and other words that evoked aversion to the sensibility of an ordinary person. The respondents listed the euphemisms they commonly used when speaking about these taboo words. Frequency count, percentage, ranking, and chi-square were used to interpret the data. Results showed that the respondents used 10,529 euphemisms for 62 taboo words under six groups. Both variables were found significant at .05 level of chi-square. Euphemisms were effectively utilized to conceal the socially unacceptable words in Iliganon's speech.
\end{abstract}

Keywords: euphemisms, linguistic taboo, Iliganons, social harmony

\section{Introduction}

Language is used to transmit experiences to others, but according to Chamber (1995), people find it hard to believe that in a simple conversation, the speaker tends to introduce himself - his background, feelings, emotions, and even his behavior and attitude. Language is a reflection of culture and according to Salazar (1996) people will likely get to understand his own culture and the culture of others through his own language. It is through language also that people pass on his culture because the lexicon or vocabulary of language reflects the things valued by its user.

Language has a vital role in the relationship of people in one culture, and through this language people tend to value and understand each member of his culture as well as the members of other cultures. Culture influences the subjective reality. With this, we can say that there is a direct relationship between a person's culture, perception, and even behavior. Human behavior in reaction to his perception of his environment is a result of his cultural foundation or cultural conditioning. According to Perucci and Knudsen (1983:18), "it is the culture which makes one behave the way he does and thus binds the members of the society together..."

Understanding cultural values helps us to understand human behavior as well. Ethel Albert (in Samovar and Porter, 1995:83) says that a "value system represents what is expected or hoped for, required or forbidden." The values stand as social guidance to people that open up cultural standards of his society and ensure how he should move or behave. It specifies what is good, bad, right, wrong, what is due or not, what is valuable or not, and what is in order or not. These values act as buoy for action, work and words for every individual. One of the most important factors that motivate and control the Filipino's conduct is the desire to be accepted by his society (Panopio and Rolda, 1988). 
The fear to be left out and mocked is the reason why almost all of the Filipino's moves and acts are in accordance with what people say, perceive, and think of him. He endeavors to know how to adjust to his social environment. We can therefore say that language, society and culture are interrelated with one another. Language is part of the entire culture. The social values help to understand the action, work, and words that the individual speaks. It is therefore hard to detach language from culture. It is the people in this culture who agree to make or create words, what words to accept or reject, and so the meaning that is given to the words in his language are determined by the culture where he belongs. It is the people who create the meaning of every word. We can say that there is no right or wrong, no due or undue, and there is no rude or dirty word either. Rodman and Fromkin (1983:226) clearly state that there "can't be anything about a particular string of sounds which make it intrinsically clean or dirty, ugly or beautiful... What acts or words are forbidden reflect the particular customs and views of the society. Some words may be used in certain circumstances and not in others..."

\subsection{Taboo and Euphemism}

The act, work, or word that is forbidden to be done or said in a particular culture is considered taboo. If the act or work is taboo, referring to that act or work is also taboo. It means that if it is marked as forbidden, talking about that act is also forbidden. The word is considered by society as inappropriate for it can cause pain or insult to their fellow, thus, they tend to use another word that will hide the real meaning of this particular word. This is society's law of forbidden that pushes every individual to use or create another word to replace this forbidden word (Wilson, 1993).

The levitation of taboo words and ideas has pressured people to create euphemisms. In many societies including the Filipino society, as much as possible, discussing or mentioning the abstract word death is unacceptable. This word seems to create an atmosphere of sadness between people who talk about it. Hence, instead of using the word death or dead, people try to use the words gone, leave permanently this world, rested, passed on, or taken by God Almighty.

\subsection{Metaphorical Extension of Words}

Filipino conservatism is also shown in how they address their body parts. From childhood, parents raise their children to avoid directly naming the most private parts of their body. Instead, they use another word or words to refer to these. For example, instead of saying vagina, they use flower in referring to the private part of their daughter and bird to refer to the private part of their son. In using the aforementioned euphemism, it shows that a word or group of words contain not only its real linguistical meaning or denotation but as well as its linguistical interpretation or connotation. In this case, the cultural meaning can be ineffable through the process of semantic widening or extension and shifting. This process is the metaphor that is dependent to cultural experiences, according to Lahoff and Johnson (in Bonvillain, 1993:72). Analyzing the metaphor contributes to a clear understanding in developing a cultural reality because our ordinary concept on how we are going to think and act is a fundamentally natural metaphor.

Bonvillain (76) gives an example with the metaphorical extension of the word mother. The metaphors of being a mother is extended to the universe and agriculture because it has the characteristic of being a mother - fruitful and it gives life to the form of plants and food. In giving life to plants and food, the humanity is being cared and sustained by the terrain and countryside.

The metaphorical shift is shown in the example of suso (breast) and bundok (mountain). The characteristic of a mountain is transferred to the breast which is bulging on a plain where the breast is also bulging on the chest especially in a woman. In this, we can say that in doing the metaphoric comparison, we need to associate the two compared things like being a mother to universe and countryside and suso to bundok (mountain).

\subsection{Background of the Study}

The use of language and meaning can be learned by people of all cultures and all who belong to that culture have their own distinct experiences that shape the use and meaning of the language. The City of Iligan is Iliganon's community that uses Cebuano language. The city is in the southern part of the Philippines that also observes cultural values being expressed through language. Language is an important tool that can explicitly express ideas that have negative impact on the hearer or effectively "hide" these unpleasant words by using euphemisms. Consequently, this study aimed to discover the euphemisms used by selected Iliganons living in the City of Iligan to avoid the use of words considered taboo that can harm the sensibility and feelings of their fellowmen. These taboo words referred to parts of the body and all negative excretions from it and negative criticisms or carps towards a person and his unacceptable behavior to society. 
It was assumed that there was a significant difference on the number of euphemisms used to replace taboo words and/or words that could hurt the feelings of the respondents grouped according to their educational qualification and gender.

\section{Methodology}

Both qualitative and quantitative designs were used in the study. The descriptive method was utilized to discuss comprehensively the euphemisms used by the respondents to replace words considered taboo that the Iliganons normally include in their speech. The data were taken from selected barangays of the city. The area covered the city proper going towards outlying areas using the open-ended questionnaire designed as a tool to gather the data and interview as verification instrument.

A three-part questionnaire was constructed and administered to 260 respondents. The first part contained the preliminary portion which gave information on the study and asked for data about the respondents. The second and third parts listed the usual taboo words which were considered vulgar and socially unacceptable. The second part was on physical terms subdivided into private/intimate parts of the body, physical movement/action, and dirt/impurities excreted by the body. The third part contained taboo words used in giving adverse criticism or finding fault which were subdivided into physical defects in the upper body/head, lower part of the body, and negative behavior.

Thirty-one (31) taboo words were listed for physical terms and another 31 taboo words for adverse criticism or physical flaw were given. Both parts were open-ended to allow inclusion of words which the respondents deemed applicable. The respondents listed the euphemisms they usually used in lieu of the words considered taboo. One taboo word may elicit as many euphemisms as used by the respondents.

There were 260 respondents in the study who were born, raised, and still lived in Iligan City with at least 21 years of age during the study. Quota, purposive, and convenience samplings were used. Quota sampling was used to get the desired number of respondents; purposive was used to select the respondent-validators while the convenience sampling was used in the administration of the questionnaire. Any Iliganons from the identified barangays who met the criteria became the respondents for the research. From among the respondents, 20 were selected not only to answer the questionnaire administered to them but acted likewise as validators/informants on responses that needed verification or clarification.

Frequency count, percentage and ranking were used a positional statistical instruments for the euphemisms. Chisquare was used to test the significant difference between the respondents grouped according to their educational qualification - professional and non-professional - and gender as male and female.

\section{Analysis}

Meanings don't reside in words, they reside in people who belong to a specific speech community, Richards claims (in Griffin, 1997:57). Language only has its meaning in a context. Giving meaning to language becomes effective only through common experiences between encoder and decoder. Aside from this, the effective delivery of message depends on careful selection of words. Adjustment of the words according to society's standard, and avoiding words that can hurt the ears and feelings of others pressure the people to create words than are acceptable to the society.

According to the semantic theory of Richards, language is metaphorical in nature so using metaphors can help to avoid misunderstanding between its users (Griffin, 1997). He considers the mind as section coordinator that continually combines separate ideas that create a new idea. When we use a metaphor, we have thoughts of different things actively put together and supported by a single word or phrase whose meaning is a resultant effect of their action. The use of metaphor is not for decoration or to dress up the expression only but to give clarity and create common experiences. The use of metaphor is a process of observing and experiencing the world through the eyes and use of analogy. Therefore, the message that will be sent that consists of word or group of words that is not acceptable to the decoder or society will be pleasing or nice to hear by using metaphor and in creating euphemisms.

\subsection{The Euphemisms of the Respondents}

The listed 62 taboo words in the questionnaire elicited 10529 euphemisms with 5223 euphemisms for physical terms and 5306 euphemisms for adverse criticisms or finding fault on others. The subcategories shall be discussed separately. 


\subsubsection{Euphemisms Used for Human Anatomy}

A total of 5223 euphemisms were given by the 260 respondents for 31 listed taboo words. Of this number, 2098 euphemisms referred to 9 taboo words for private or sexual parts of the body, 1747 euphemisms were listed to allude to 12 taboo words referring to wastes excreted by the body, and 1378 euphemisms were listed for 10 words considered taboo referring to body movements or action especially those representing sexual activity.

Examples of euphemisms representing private or sexual parts of a person were bulaklak/bulak (flower), flower, sunflower, bibingka/bingka (rice cake), pekpek, pepe, monay, hotdog bread, and holy hole for the taboo word bilat (vagina) and for the male organ uten/oten (penis) terms as hotdog/jumbo hotdog, luso, buto, armas (arms), halas (snake), pikoy (parrot), saging (banana), microphone, kandila (candle), and tenten/tintin (for babies and young boys) were given.

Culturally, Filipinos in general metaphorically regard a young Filipina lady as a tender flower that needs to be handled gently. Hence, her very private or intimate part is also referred to as a bulaklak/bulak (flower), flower, or sunflower. Sunflower denotes being big in size of the vagina which is meant to be a joke or humorous remark. Similarly, bibingka/bingka, a kind of rice cake, usually has a linear break on its surface when it is cooked or done and is commonly likened to a woman's vagina. Pekpek and pepe are usually terms used for babies and small girls while monay is for big or mature girls. Monay is a big round shaped bread with a division at the center. Hotdog bread is easily understandable while holy hole is also referred to a mature woman.

On the other hand, hotdog or jumbo hotdog is closely associated with a man's uten/oten (penis) with jumbo hotdog denoting being large in size and length. Luso and buto, although still considered vulgar, are lesser in vulgarity than the original term uten/oten. For small boys and infants, tenten/tintin is used which is the shortened form of the original uten/oten. The sound of tenten/tintin is playful and endearing and hence, it loses its vulgarity. Pikoy, a kind of parrot, is also a popular euphemism for uten/oten because of its curved beak. The other euphemisms like halas (snake), kandila (candle), and microphone are also used because of its shape and length. Armas (arms) is also a favorite because of its meaning.

For wastes excreted by the human body which are taboo, euphemistic terms as eta, etat, etats, etah (modified word reversals for tae 'feces'), hugaw, dumi (both mean literally dirt), submarine/yellow submarine, ipot (bird excreta) and tibé (hard excreta) were used to stand for tae (feces or excrement), tubol (very hard or stone-like feces) or igit (very watery feces). For body odor especially emanating from the underarms, euphemisms kilikili power, perfume, aslum (sour), amoy kambing (smells like goat), putok (firework sound) and b.o. (body odor) were the favorites.

Fecal excretion by the human body signifies stink, ultimate dirt, disease and abhorrence. Hence, the mere mention of tae (feces) is considered negative to the ordinary person's sensibility and changing the term by using euphemism is more acceptable. So the word had been modified to sound differently as eta, etat, etats, or etah or using an entirely different local word hugaw or dumi (dirt), submarine or yellow submarine signifying the buoyancy of the excrement and sometimes using yellow as a distinctive color of the feces. Ipot is another local term for excrement normally of birds and small mammals while tibe signifies hard fecal excretion but not fully out of the bowel or anus. On the other hand, kilikili means underarm and the stink that comes out of it is referred to as power, hence kilikili power. To hide the meaning of the very foul smell coming from the underarm, perfume is used or aslum (sour) or amoy kambing (smells like goat). A goat is an animal which does not like water or does not take a bath so it connotes bad smell. Putok locally in the Philippines connotes foul smell which refers to the underarm kind of stink.

For bodily movement, euphemisms were used for having menstruation (gidugo, nireregla), moving the bowels (nalibang), throw up (nagsuka), to fart (nag-utot), cleaning the nosetrils (nangalungat), or having sexual intercourse (nag-iyot). For gidugo/nireregla, some euphemisms used were mens, ga-mens, gi-mens, may mens and nag-mens (shortened form of menstruation) or gi-red tide, red tide, bisita/gibisita (visited or having visitor) may bisita or naay bisita (has visitor), midunggo ang barko (ship landing), naay red spot (there is red spot), lady in red, may hemorrhage (has hemorrhage), and red flag is up. For malibang (to excrete or move the bowels) the respondents gave such euphemisms as mag-deposit/nag-deposit, mag-cr or nag-cr (comfort room, toilet), nagpagawas sa hugaw (empty or remove the dirt), nalingkod sa trono (sitting on the throne), unloading, magsuko ang lubot (the ass [behind] is angry), and success. The term success for nalibang was an off-shoot of a televised advertisement on the use of an anti-constipation drug. For mag-iyot/nag-iyot (having sexual intercourse), the respondents created euphemistic terms as nag-i (shortened for nag-iyot), nag-angkla (anchored), push and pull, nagtars, jer-jer, dyogdyog, sapin-sapin and tordyak. Nag-angkla (anchored) and push and pull are easy to figure out. 
Tordyak is from the English term turn the jack, an instrument used in changing a flat tire of a vehicle. From turn the jack, it has evolved to tordyak. Except for sapin-sapin which locally has the literal meaning of one over the other, the terms were all coined and had no exact literal meaning. Nevertheless, due to the preponderance of the use of jer-jer, dyogdyog, and tordyak for sexual intercourse, the informants claimed that anybody would always allude these words to having sexual intercourse and would have no other meaning attached to it.

\subsubsection{Euphemisms for Negative Personal Description}

A total of 5306 euphemisms were used for 31 taboo words describing defects of a person in the upper body part especially the head, in the torso or the body, and to describe bad or negative behavior or work done by a person. For defects in the upper body especially the head, 2506 euphemisms were used instead of 15 words/group of words which are considered taboo. A total of 1426 euphemisms were listed for 8 defects or flaws in the physique, and 1374 euphemisms were given for 8 taboo words describing negative or bad behavior.

For defects in the upper part of the body particularly the head, euphemisms used were siga (bright), siga og mata (bright eyes), sigahon, sigaha, simats, simag, owl (the night bird), dakma, dakmat, dakmats (blending of words dako 'big' and mata 'eyes'), budmat, beautiful eyes, batli, batlibs, for luwa mata, budlat (bulging eyes), dakog mata (bulging big eyes), libat (cross eyed), no earth (for walay kalibutan [does not know]), walang signal (no signal), flying ears, kojak (after the bald actor), dragon breath, and nagyaka ang ilong (the nose flopped). For persons who have depression or not in their proper mind set, the euphemisms given were katok, katokon/katukon, nakatok, katik, kalay, kalay-kalay, amaw (Cebuano terms), taralala, may singko sa utok (with five centavos in the brain), may tililing (or tiriring), praneng/praning (colloquial word) for buang or insane, simpleton or boob.

For defects in the torso or body, some euphemisms given were hubag/hubagang ate oy, hubag si ate, booba, boobsie/boobsy, kapayas, kapayason, papaya, papaya queen, dakug kapayas, kapayason ug dibdib for taboo words dakug suso, dako ug totoy (big chested or with big breasts). For mataba or tambok (plump or obese) the euphemisms given were baboy (pig), gababoy (being/looks like a pig) chubby or chabe, Dabiana or dabyana or tabatsoy. For having scabbies on the skin, some euphemisms used were naay kamunggay (with moringa, a leafy vegetable), gikirkir, kagerds, and scaby doo (modified name of Scooby Doo).

Hubagang Ate $\mathrm{Oy}$ is a title of a Cebuano song about a woman who is very shapely with full or very big breasts. Hence, for a woman with big breasts hubag si ate was also used which was extracted from the song title. Hubag is a Cebuano term which literally means swollen. Papaya, a type of fruit, also symbolizes a woman's breast hence, the terms papaya queen, dakug kapayas (big papaya), kapayas, kapayason (like a papaya), kapayason ug dibdib (papaya-like breasts). Colloquially, a woman's breasts are also called boobs, hence the euphemisms booba, boobsie or boobsy.

The pig is a domesticated animal being fattened to be sold. Hence, a fat or obese/plump person is colloquially called baboy and when one gets plump, the term gababoy becomes applicable. Chubby (chabe) is an endearing term for a plump person but tabatsoy is a modified term for taba (fat). In the Philippine movies, an attractive but obese comedienne had a screen name of Dabiana and the name became applicable to women who are obese or fat.

Kagid is a local word for scabbies and gikirkir and kagerds are modified versions while kamunggay (moringa) has small round leaves alluded to scabby flakes off the skin. Scaby doo is an alteration of the name of Scooby Doo, a dog cartoon character, with scaby to apply to the skin disease.

Eight (8) words considered taboo that described negative behavior or socially unacceptable work elicited 1374 euphemisms. Some of these euphemisms were mga damong ligaw (literally wild grasses) anak ni Magdalena (child of Magdalena), chokla/jokla, shoyot/syoyot, charing, walang matris (no womb or uterus), girlie-girlie, bardot, may daga sa dibdib, bugnaw simod (cold snout or muzzle), puti og itlog (literally white eggs), kurigat/kurikaton, prosti (shortened form of prostitute), karingking, igatz or igatzky, G.R.O. (guest relations officer), GRX (modified form of G.R.O.), gikatlan, Magdalena, mukhasim, prinsesang di tumatawa (unsmiling princess), kasab-itan ang nawong, palahikay, gabula ang baba, and chess champ.

Mga damong ligaw and anak ni Magdalena refer to the child/children of prostitutes while chokla/jokla, shoyot/syoyot, charing, walang matris (no womb or uterus), girlie-girlie and bardot all refer to males belonging to the third sex or gays. The Cebuano word for sissy is bayot while the Filipino term is bakla so chokla/jokla and shoyot/syoyot are modified forms for bakla and bayot. Bardot is the family name of Brigitte Bardot, a famous sexy international actress and is used as euphemism for a gay. Girlie-girlie and walang matris (no womb or uterus) also refer to gays who act and feel to be women. 
May daga sa dibdib (literally with a mouse in the chest), bugnaw simod (cold snout or muzzle), and puti og itlog (literally white eggs or testicles) are all euphemisms for a coward or one who is nervously afraid to do whatever is needed to be done.

Kurigat or kurikaton, prosti, karingking, igatz or igatzky, G.R.O., GRX, gikatlan, and Magdalena are some euphemisms for a prostitute or a woman whose repute is questionable. Kurigat, kurikaton, igatz, and igatzky are derived from a Cebuano word igat which literally means flirt. Prosti is a shortened form of prostitute while karingking is a Tagalog word which also means flirt. G.R.O. (guest relations officer) with its variant GRX is another term for a hostess who works in a bar or night club joint frequented by males. Although the woman may not be working in a bar or similar night pub, this woman who may have a questionable reputation is called by this euphemism. Gikatlan is a Cebuano word for having itchiness and an insistent desire for sex. Magdalena, on the other hand, is a Biblical woman's name representing one who is a prostitute. The name is also the title of a Philippine song about a prostitute who wanted to reform but misunderstood.

Mukhasim, prinsesang di tumatawa, and kasab-itan ang nawong, all refer to a person who is cranky and easily irritated. They are also applicable to snubs and hard to please individuals. Mukhasim comes from the words maasim na mukha (literally sour face) while prinsesang di tumatawa means princess who does not know how to smile/laugh. Kasab-itan ang nawong means a face that holds something heavy that connotes frowning and having long face.

Palahikay, gabula ang baba, and chess champ are used to refer to a person who always backbites and always has ill words for others. Palahikay means a faultfinder or adverse critic and gabula ang baba literally means foaming mouth as a result of incessant talking. Chess champ does not refer at all to the game chess. Instead, the word chess is taken from chismis/tsismis which means backbiting or talking about others behind their back normally about negative things.

\subsection{Statistical Interpretation of the Data}

The number of euphemisms given by the respondents showed several thousand percent more than the original listed taboo words. The number of euphemisms for adverse criticisms or finding fault with others were more than the number of euphemisms given for the private and intimate physical parts of a person, the physical movement or action done and the dirt and impurities being excreted by the body.

On the physical anatomy, more euphemisms were given for private and intimate parts of the body (40.17\%) followed by the dirt and impurities being excreted (33.45\%) and euphemisms for physical movement and action being third $(26.38 \%)$.

On the adverse criticisms and finding fault with others, euphemisms for the upper portion of the body especially the head ranked first (47.23\%), ranked second was defects of the body or the torso (26.88), and third was the euphemisms for negative behavior $(25.90 \%)$.

The results of the chi-square showed significant differences in the euphemisms used by the respondents grouped according to their educational qualifications (professionals and non-professionals) and their gender (male and female).

\section{Conclusion}

The Iliganons are consciously making efforts of maintaining social harmony by using words that are not unacceptable to others. They do this by using words known as euphemisms that will not hurt the feelings and sensibilities of their hearers. Instead of using words that are considered unpleasant or taboo in the social environment where they are, they consciously replace these words with either humorous or closely associated with what they mean but with less negative semantic effect. These words are euphemisms.

Consequently, the use of euphemisms in speech results in the maintenance of social harmony and avoidance of discord in society.

\section{References}

Abaya, E. \& Hernandez, J.F.C. (1998): “Salitang Bakla - Makapangyarihan? Mapagpalaya?" in The Archive: A Journal Devoted to the Study of Philippine Languages and Dialects by Constantino et al. Quezon City: University of the Philippines Press.

Bolinger, D. (1975): Aspects of Language. $2^{\text {nd }}$ ed. New York: Harcourt Brace Jovanovich, Inc 
Brinkerhoff, D.B. \& White, L.K. (1988): Sociology. $2^{\text {nd }}$ ed. W. Kellogs Boulevard: West Publishing Co.

Bonvillain, N. (2003): Language, Culture and Communication (The Meaning of Messages). $4^{\text {th }}$ ed. New Jersey: Pearson Education, Inc.

Chambers, F.K. (1995): Sociolinguistic Theory Linguistic Variation and Its Social Significance. Oxford: Blackwell.

Constantino, P. (2002): "Mga Babasahin sa Varayti at Varyasyon ng Filipino" in J.M. Peregrino et al. (eds.): Minanga. Quezon City: Sentro ngWikang Filipino.

Constantino, P. \&Atienza, M. (1996): Mga Piling Diskurso sa Wika at Lipunan. Quezon City: University of the Philippines Press.

Daiz, G. \&Desierto J. (2005): "Eufemismo sa mga Awiting Rap ng Salbakuta." Unpublished Thesis, MSU-Iligan Institute of Technology, Iligan City.

Edwards, A.D. (1979): Language in Culture and Class The Sociology of Language and Education. London: Heinemann Educational Books Ltd.

Fishman, J.A. (1973): "The Sociology of Language" in Miller, G.A. (ed): Communication, Language and Meaning (Psychological Perspectives). New York: Basic Book, Inc.

Haas, M.R. (1961):“Interlingual Taboos" in Hymes, D. (ed): Language and Culture. New York: Harper \& Row Publishers.

Lazaro, M.V. (2005):“On Euphemisms of Some Tagalog Tabooed Expressions,"Bukal Research Journal of the College of Language, Linguistics, and Literature 1 (1) May 2005.

Lim, C.A.O. (1999): "The Cebuano Verbal Taboos and Euphemisms among SET Students of MSU-IIT, Iligan City." Unpublished Thesis, MSU-Iligan Institute of Technology, Iligan City.

Mojica, L.A. (2000): "How Selected Students Describe Male/Female Language in Filipino," Philippine Journal of Linguistics 31 (1) 2000.

Montgomery, M. (1995): "Language and Gender" An Introduction to Language and Society. $2^{\text {nd }}$ ed. London: Routledge.

Panopio, I. S. \& Rolda, R. S. (1988): Sociology and Anthropology An Introduction. Quezon City: Goodwill Trading Co., Inc.

Panopio, I.S., Cordero-MacDonald, F.V., \& Raymundo, A.A. (1994): General Sociology Focus on the Philippines. $3^{\mathrm{rd}}$ ed. Quezon City: Ken, Inc.

Perrucci, D. \& Knudsen, D.D. (1983): Sociology. St. Paul, Min.: West Publishing.

Pizaro, A.P. (2002): "Language Across the Social Spectrum: The Structure and Use of the Gay Language in Iligan City." Unpublished Thesis, MSU-Iligan Institute of Technology, Iligan City.

Rawson, H. (1981): A Dictionary of Euphemisms and Other Double Talk. New York: Crown Publishers, Inc.

Rodman R. \& Fromkin V. (1983): An Introduction to Language. $3^{\text {rd }}$ ed. New York: Holt, Rinehart, and Winston.

Rubrico, J.G.U. (2006): "Linguistics para sa mga Mag-aaral ng Agham Panlipunan I [accessed March 13, 2007] http://www.Languagelinks.org.onlinepapers/wika3/html.

Salazar, A.E. (1999): Noli Me Tangere of Rizal. Quezon City: JMC Press, Inc.

Samovar, L.A. \& Porter, R.E. (1995): Communication Between Cultures. $2^{\text {nd }}$ ed. Washington: Wadsworth Publishing Co.

Santos, A.L. \& Hufana, N.L.(2003): Sining ng Komunikasyon (Teksbuk-Workbuk sa Filipino1). Iligan City: DFIW, MSU-IIT.

Sulonen, N. (2005): Taboos in My Culture/Non-verbal Communication. @hotmail.c0m: Technology of University Helsinki.

Tulio, D. (2000): Foundations of Education (Book One). Quezon City: Kalayaan Press.

Tannen, D. (1999): You Just Don't Understand. Laura Brayanan: LauraBrayanan @ hotmail.com

Wilson, K. (1993):The Columbia Guide to Standard American English. London: Columbia University Press.

Wardaugh, R. (1992): An Introduction to Sociolinguistics. $2^{\text {nd }}$ ed. London: Blackwell Publishers. 


\section{The Authors}

Prof. Marilyn Tampos-Villadolid is an Assistant Professor at the College of Education and Social Sciences, Mindanao State University-Naawan at Naawan, Misamis Oriental, Philippines. She teaches basic and major Filipino courses.

Dr. Angelina Lozada Santos is full professor at the College of Arts and Social Sciences, Mindanao State University-Iligan Institute of Technology at Iligan City, Philippines. She teaches undergraduate and graduate Filipino courses. Her research interests include local and folk literature, Filipino language varieties and variations, and culture. 